\title{
Experimental induction of luteal cyclicity in roe deer (Capreolus capreolus)
}

\author{
A. J. Sempéré ${ }^{1}$, R. Mauget ${ }^{1}$ and P. Chemineau ${ }^{2}$ \\ ${ }^{1}$ Centre d'Etudes Biologiques de Chizé (CNRS), 79360 Villiers en Bois, France; and ${ }^{2}$ INRA, \\ Station de Physiologie de la Reproduction, 37380 Nouzilly, France
}

\begin{abstract}
Summary. Concentrations of progesterone and luteinizing hormone in plasma were analysed for two consecutive years in samples from nonpregnant female roe deer. Three animals were treated with monthly prostaglandin injections $(325 \mu \mathrm{g}$ cloprostenol) from October 1989 to April 1990 and from October 1990 to March 1991, and three were kept as controls. In control animals, a small increase in progesterone concentrations in July 1990 occurred at the same time as the commencement of the rut in other husbanded roe deer. In prostaglandin-treated animals, progesterone concentration was high at the time of the rut and remained so until late February 1990. After the next rut (August 1990), progesterone concentration remained high until March 1991. Between October and February-March, injections of prostaglandins induced dramatic, but temporary (lasting $72 \mathrm{~h}$ ), decreases in plasma progesterone concentrations, indicating luteal regression and subsequent ovulation. We infer that roe deer can ovulate repeatedly and should therefore not be regarded as an obligate monoestrous species.
\end{abstract}

Keywords: corpus luteum; luteinizing hormone; progesterone, prostaglandin, roe deer

\section{Introduction}

Most female cervids are polyoestrous during the breeding season and strictly anoestrous for the rest of the year (white-tailed deer, Odocoileus virginianus, Knox et al., 1988; red deer, Cervus elaphus, Adam et al., 1985; fallow deer, Dama dama, Asher 1985; Père David's deer, Elaphurus davidianus, Curlewis et al., 1988). In Elaphurus davidianus, length of the oestrous cycle ranged between 18 and 21 days, although some long cycles were noted (Curlewis et al., 1988). This has also been noted in red deer (Guinness et al., 1971; Adam et al., 1985, 1989) and indicates the possibility of prolongation of luteal life in these polyoestrous species. In the monoestrous species, roe deer, the rut occurs in summer (July-August) and fawning in May or early June, after a gestation of about 300 days incorporating a period of embryonic diapause (Stieve, 1950; Wandeler, 1974; Sempéré, 1977; Sempéré et al., 1989). After the rut, plasma progesterone remains high until May, even in nonpregnant females, indicating the persistence of a corpus luteum (Hoffmann et al., 1978), though there is no laparoscopic evidence.

This paper reports a test, by means of monthly administration of prostaglandins to induce luteal regression, of the hypothesis that the roe deer is not an obligate monoestrous species and that new ovulations can occur after experimental induction of luteal regression.

\section{Materials and Methods}

\section{Animals and management}

Six adult roe deer were kept in a grassed park $(0.5$ ha) from June 1989 to June 1991 at the Centre d'Etudes Biologiques de Chizé in France $\left(46^{\circ} 10^{\prime} \mathrm{N}, 0^{\circ} 30^{\prime} \mathrm{E}\right)$. In spring 1989, all had fawns; fawns were removed soon after birth 
and reared for another study. Throughout the present study, females were not accompanied by males. Three females were treated with prostaglandins and three females were kept as controls.

\section{Prostaglandin treatment}

From October 1989 to April 1990 and from October 1990 to March 1991, three deer were given monthly i.m. injections of $325 \mu \mathrm{g}$ cloprostenol ( $\cdot 3 \mathrm{ml}$, Estrumate; Imperial Chemical Industries plc, Cheshire, UK).

\section{Blood sampling}

Animals were manipulated in a system designed to reduce the stress of handling. They were moved gently from the feeding area through a darkened shed and then into trap boxes where they were sedated lightly without handling. A single i.m. injection of xylazine hydrochloride (Rompun; Bayer Leverkusen, Germany), at $0.6 \mathrm{mg} \mathrm{kg}^{-1}$. Choice of sedative is important, as some drugs, such as etorphine and acepromazine, abolish episodic fluctuations of luteinizing hormone (LH) (Peet \& Lincoln, 1977). Rompun does not have this effect and alone, or with ketamine, has been widely found satisfactory for studies of cervid reproduction (Van Mourik \& Stelmalsiak, 1985; Bubenik et al., 1987; Fennessy et al., 1988; Suttie et al., 1989; Curlewis et al., 1991). Moreover, we have found that progesterone is not affected. Plasma progesterone concentrations measured in physically restrained female roe deer $\left(3.65 \pm 0.06 \mathrm{ng} \mathrm{ml} \mathrm{m}^{-1}\right)$ were not different from those $\left(3.73 \pm 0.17 \mathrm{ng} \mathrm{ml}^{-1}\right)$ detected after administration of Rompun $\left(2.5 \mathrm{mg} \mathrm{kg}^{-1}\right)\left(\mathrm{A} . \mathrm{J}^{\mathrm{S}}\right.$. Sempéré, unpublished data).

After the blood sample was taken, the animals were released back into the shed and then into the park. From June 1989 to January 1990, two blood samples were taken twice a month (day 0, before injection of prostaglandins, and day $0+72$ h). From February 1990 to March 1991, every 2 months, all females were sampled daily for the first week after the prostaglandin injection, then every 2 days for 20 days or 30 days (at the time of the rut, this period was extended to 45 days).

Blood samples were centrifuged at $2000 \mathrm{~g}$ for $15 \mathrm{~min}$ immediately after collection. Samples were stored at $-20^{\circ} \mathrm{C}$ before radioimmunoassay. All samples were assayed in bulk after each series was complete. We stopped treatment when no increase in progesterone was recorded.

\section{Hormone assays}

Progesterone concentrations in plasma were measured by extraction radioimmunoassay using antibody raised in rabbits against a conjugate of progesterone $11 \alpha$-hemisuccinate and bovine serum albumin (Sempéré et al., 1989) and $\left[{ }^{3} \mathrm{H}\right]$ progesterone (3.55 Tera Becquerel $\mathrm{mmol}^{-1}$; C. E. A., Saclay). The sensitivity was $6.25 \mathrm{pg} \mathrm{per} \mathrm{tube}\left(0.06 \mathrm{ng} \mathrm{ml}^{-1}\right)$. At the $50 \%$ displacement level for $50 \mathrm{pg}$ progesterone per tube, crossreactivities were $1.7 \%$ for $20 \beta$-hydroxyprogesterone and $<0.3 \%$ for oestradiol, cortisol, androstenedione, androstenediol, cortisone, $20 \alpha$-hydroxyprogesterone and testosterone. The mean recovery from extracts of deer plasma was $97.7 \pm 0.01 \%$ ( \pm SEM). Interassay coefficient of variation was $12 \%$ and intra-assay coefficient of variation was $6 \cdot 2 \%$.

Plasma LH concentrations were analysed by radiommunoassay, as described by Sempéré \& Lacroix (1982), with LH M3 as the ligand, which has 1.5 times the activity of standard NIH-LH-SI (Jutisz \& Courte, 1968). The antiserum did not crossreact with the ovine follicle-stimulating hormone, growth hormone or thyroid-stimulating hormone. Assay sensitivity was $0.2 \mathrm{ng} \mathrm{ml}^{-1}$ and the intra-assay coefficient of variation was $<5 \%$.

\section{Statistical analysis}

For calculation of mean values across control animals for the transitory LH peak, it was necessary to normalize data: two methods were used. First, the rises in progesterone were synchronized and the preceding rises in LH were averaged. Second, the highest LH values preceding the rises in progesterone were synchronized. The second method was adopted because preliminary analysis indicated that the precise courses of the rise in progesterone were very variable among animals. Concentrations are presented with the standard errors of the means. Comparisons between successive monthly means were made by analysis of variance.

\section{Results}

\section{Plasma progesterone profiles}

A small increase in progesterone secretion preceded the first oestrus in all roe deer in July (Fig. 1a). A subsequent decrease was followed by an increase in early August (the normal rutting period). Plasma progesterone concentrations remained continuously high until late February to early March. A significant decrease in plasma progesterone concentrations was evident in April in the 
first year of the study (March versus April: $P<0.001$ ) and in March in the following year (February versus March: $P<0.001$ ). The lowest values for progesterone secretion were recorded from May to July.

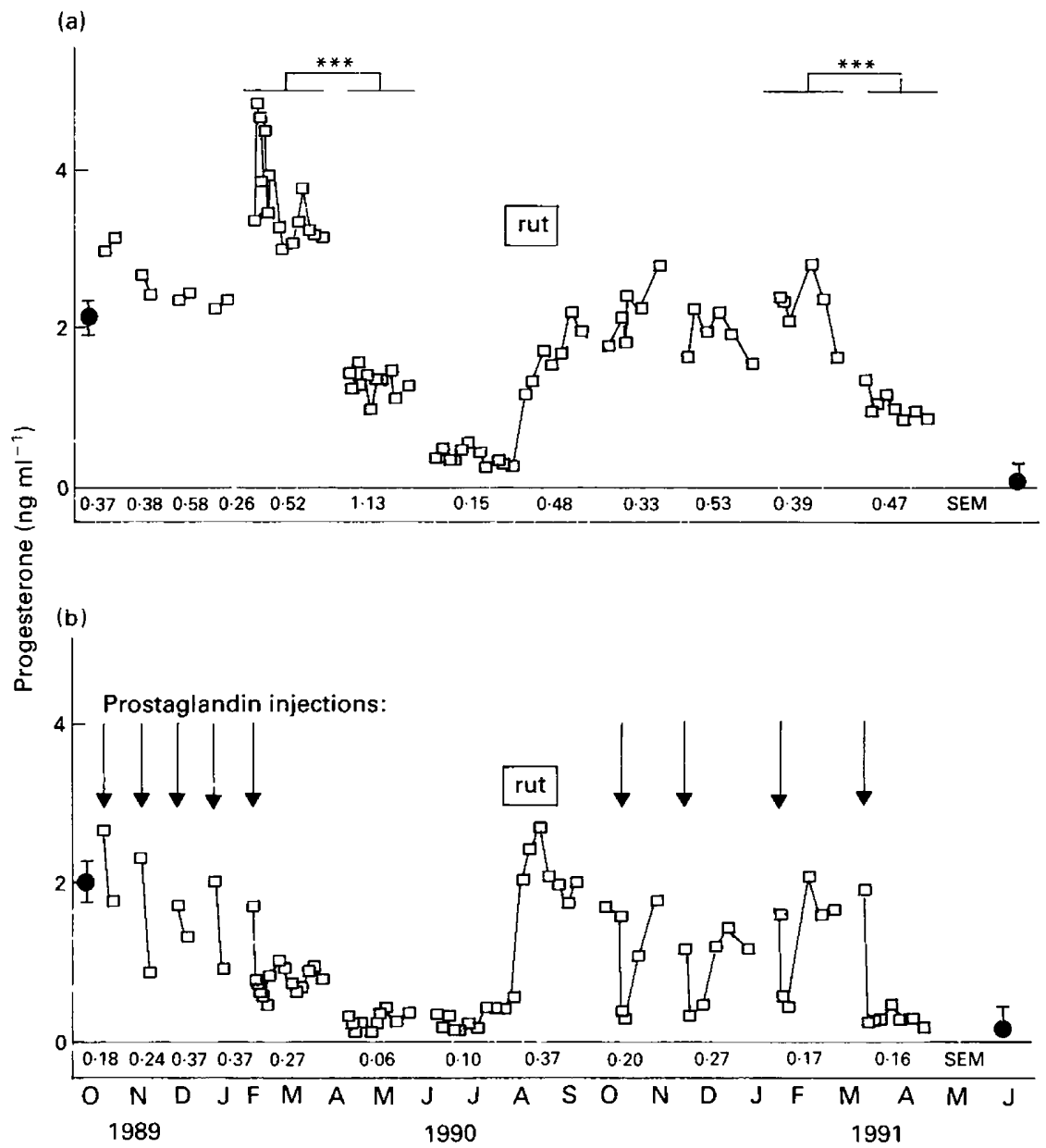

Fig. 1. Seasonal pattern of mean plasma progesterone concentrations in nonpregnant female roe deer $(n=3)$, (a) control and (b) subjected to periodic injections of prostaglandin $(\downarrow)$. Symbols $(-)$ at the extreme left and right indicate the mean $( \pm$ SEM) progesterone concentrations measured during the 3 months preceding and the 2 months after the experiment. The SEMS for the pooled series of measurements are presented at the bottom of the graph. Significant differences (ANOVAR) of means between one series and the preceding series are indicated $(* * * P<0 \cdot 001)$.

In experimental deer (Fig. Ib), as in controls, an increase in plasma progesterone concentrations was observed in August after a small and transitory progesterone cycle in July. Injections of prostaglandins, starting in early October, induced dramatic decreases in progesterone concentrations $(P<0.001)$ within $72 \mathrm{~h}$. This decrease was followed by a subsequent increase but only between October and late February to early March. Plasma progesterone concentrations remained significantly reduced after the last injection in February (first year) and early March (second year); these low concentrations persisted until July. 


\section{LH and progesterone pattern around spontaneous oestrus and after prostaglandin injection}

Plasma progesterone concentrations rose progressively after the LH peak was recorded (Fig. 2a). In experimental females (Fig. 2b), plasma progesterone decreased rapidly from $2 \mathrm{ng} \mathrm{ml}^{-1}$ at the time of prostaglandin injection to $0.6 \mathrm{ng} \mathrm{ml}^{-1} 24 \mathrm{~h}$ later and remained low for four consecutive days. An LH peak was noted 4 days after prostaglandin injection. In a similar pattern to that presented in Fig. 2a, plasma progesterone concentrations rose 2 days after the LH peak (6 days after treatment) and reached significantly higher values on day 8 (day 2 versus day $8: P<0.005$ ).

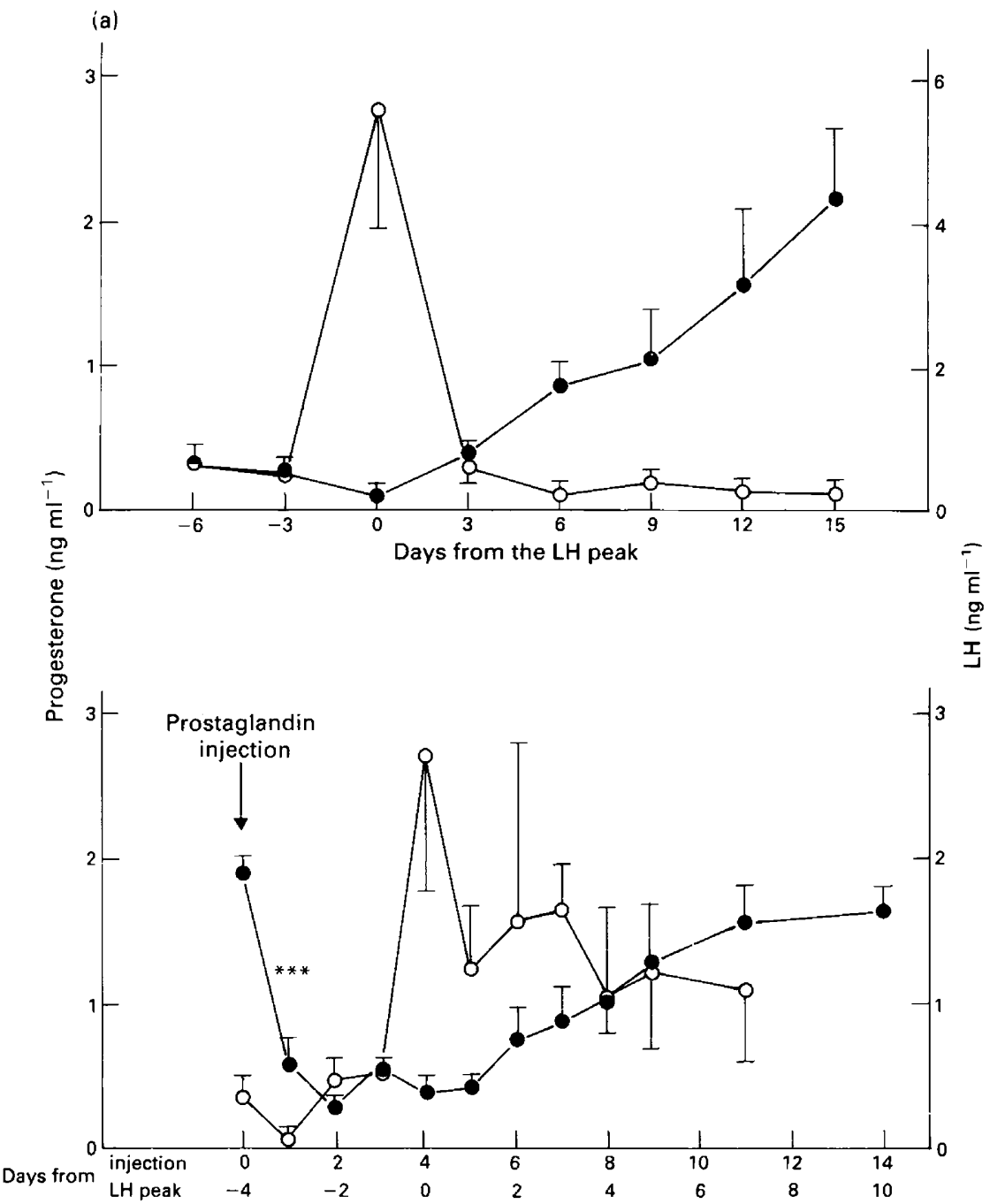

Fig. 2. Patterns of plasma luteinizing hormone $(\mathrm{LH})(\mathrm{O})$ and progesterone $(\bullet)$ secretion in (a) control roe deer $(n=3)$ around the time of the single ovulation of the natural rut and (b) treated female roe deer $(n=3)$ immediately after injection of prostaglandins $(\downarrow$, October and December 1990, January 1991). Mean normalized (see text) values are presented with $95 \%$ confidence limits. 


\section{Discussion}

In female roe deer, ovulation occurs spontaneously at the time of the rut in July-August and, if fertilization does not take place, plasma progesterone concentrations remain high until February or March (Hoffmann et al., 1978; Schams et al., 1980). Ovariectomy abolishes progesterone secretion (Sempéré, 1977), indicating that the progesterone is of luteal origin (in some cervids, an adrenal origin of progesterone has been demonstrated: white-tailed deer, Plotka et al., 1983; fallow deer, Asher et al., 1989; red deer, Jopson et al., 1990).

Prostaglandins (PG) induce luteolysis in most mammals (Scaramuzzi et al., 1974; Spicer et al., 1981). Furthermore, there is a close relationship between $\mathrm{PGF}_{2 \alpha}$ and ovarian oxytocin, which is implicated in the destruction of the corpus luteum. Prostaglandin injection has been observed to induce a greater increase in oxytocin secretion during the breeding season than during anoestrus in cervids (Flint et al., 1991). Although plasma PGF ${ }_{2 a}$ has never been measured in cervids, episodic fluctuations of peripheral plasma concentrations of 13,14-dihydro-15-keto prostaglandin $F$ (PGFM), which is the pulmonary metabolite of $\mathrm{PGF}_{2 a}$, were observed during luteal regression in fallow deer (Asher et al., 1988). Moreover, administration of cloprostenol on day 13 of the oestrous cycle in fallow deer induced a rapid decline in plasma progesterone concentrations, followed by oestrus a few days later (Asher et al., 1990). These observations provide strong support for our suggestion that cloprostenol, which reduced progesterone to $25 \%$ of its pretreatment concentration, did so by abolishing the corpus luteum.

In fallow deer (Asher et al., 1990), the entire preovulatory LH surge is completed within $18 \mathrm{~h}$. In roe deer, our daily sampling protocol has clearly shown a significant increase in $\mathrm{LH}$ before ovulation (Fig. 2). The increases in progesterone and $\mathrm{LH}$ after the presumed luteolysis indicated that ovulation had occurred. We, therefore, suggest that repeated luteal cycles are within the capability of roe deer from July to February-March, but this capability abates by April.

Direct confirmation that the luteal cycles we describe do indicate repeated ovulations would require laparoscopic examination. Indirect evidence comes from one female roe deer which entered this experiment (first prostaglandin injection on 17 December 1989), but died 12 days later. In this animal, a new corpus luteum was found in one ovary while traces remained of the previous one, which was presumably destroyed by the prostaglandins.

The authors thank A. Lacroix, Z. Marillet and C. Trouve for performing the assays and technical assistance. We acknowledge $N$. Guillon for assistance with blood sampling and animal care and M. Suire (Mounet CASA) for providing food for the animals. We thank C. Mauget for computer programming. We also thank S. J. G. Hall for critical reading of the manuscript.

\section{References}

Adam, C.L., Moir, C.L. \& Atkinson, T. (1985) Plasma concentrations of progesterone in female red deer (Cervus elaphus) during the breeding season, pregnancy and anoestrus. Journal of Reproduction and Fertility 74, 631-636.

Adam, C.L., Moir, C.L. \& Shiach, P. (1989) Plasma prolactin concentrations in barren, pregnant and lactating red deer (Cervus elaphus) given melatonin to advance the next breeding season. Animal Reproduction Science 18, 77-86.

Asher, G.W. (1985) Oestrous cycle and breeding season of farmed fallow deer, Dama dama. Journal of Reproduction and Fertility 75, 521-529.

Asher, G.W., Peterson, A.J. \& Watkins, W.B. (1988) Hormonal changes during luteal regression in farmed fallow deer, Dama dama. Journal of Reproduction and Fertility 84, 379-386.

Asher, G.W., Peterson, A.J. \& Dunganzich, D. (1989) Adrenal and ovarian sources of progesterone secretion in young female fallow deer (Dama dama). Journal of Reproduction and Fertility 85, 667-675.

Asher, G.W., Fisher, M.W., Smith, J.F., Jabbour, H.N. \& Morrow, C.J. (1990) Temporal relationship between the onset of oestrus, the preovulatory LH surge and ovulation in farmed fallow deer, Dama dama. Journal of Reproduction and Fertility 89, 761-767.

Bubenik, G.A., Schams, D. \& Coenen, G. (1987) The effect of artificial photoperiodicity and antiandrogen treatment on the antler growth and plasma levels of $\mathrm{LH}, \mathrm{FSH}$, testosterone, prolactin and alkaline 
phosphatase in the male white-tailed deer. Comparative Biochemistry and Physiology 87A, 551-559.

Curlewis, J.D., Loudon, A.S.I. \& Coleman, A.P.M. (1988) Oestrous cycles and the breeding season of the Père David's deer hind (Elaphurus davidianus). Journal of Reproduction and Fertility 82, $119-126$.

Curlewis, J.D., McLeod, B.J. \& Loudon, A.S.I. (1991) LH secretion and response to GnRH during seasonal anoestrus of the Père David's deer hind (Elaphurus davidianus). Journal of Reproduction and Fertility 91, $131-138$.

Fennessy, P.F., Suttie, J.M., Crosbie, S.F., Corson, I.D., Elgar, H.J. \& Lapwood, K.R. (1988) Plasma LH and testosterone responses to gonadotrophin-releasing hormone in adult red deer (Cervus elaphus) stags during the annual antler cycle. Journal of Endocrinology $117,35-41$.

Flint, A.P.F., Sheldrick, E.L., McCann, T.J., Brinklow, B.R. \& Loudon, A.S.I. (1991) Prostaglandin-induced secretion of oxytocin and prolactin in red (Cervus elaphus) and Père David's (Elaphurus davidianus) deer hinds: evidence of luteal origin. General and Comparative Endocrinology 83, 432-438.

Guinness, F.E., Albon, S.D. \& Clutton-Brock, T.H. (1971) Factors affecting reproduction in red deer (Cervus elaphus). Journal of Reproduction and Fertility 54, 325-334.

Hoffmann, B., Barth, D. \& Karg, H. (1978) Progesterone and estrogen levels in peripheral plasma of the pregnant and nonpregnant roe deer (Capreolus capreolus). Biology of Reproduction 19, 931-935.

Jopson, N.B., Fisher, M.W. \& Suttie, J.M. (1990) Plasma progesterone concentrations in cycling and ovariectomised red deer: the effect of progesterone supplementation and adrenal stimulation. Animal Reproduction Science 23, 61-73.

Jutisz, M. \& Courte, C. (I968) Hormone lutéinizante (LH) de mouton. I Obtention a l'état apparemment homogène. Etude physicochimique et biologique. General and Comparative Endocrinology' 11, 562-574.

Knox, W.M., Miller, K.V. \& Marchinton, R.L. (1988) Recurrent estrous cycles in white tailed deer. Journat of Mammalogy 69, 384-386.

Peet, M.J. \& Lincoln, G.A. (1977) Blockade of episodic gonadotrophin secretion by immobilon in ovariectomized ewes. Journal of Reproduction and Fertility 50, 97-100.

Plotka, E.D., Seal, U.S., Verme, L.J. \& Ozoga, J.J. (1983) The adrenal gland in white tailed deer: a significant source of progesterone. Journal of Wildlife Management 47, 38-44.

Scaramuzzi, R.J., Boyle, H.P., Wheeler, A.G., Land, R.B. \& Baird, D.T. (1974) Preliminary studies on the secretion of prostaglandin F from the autotransplanted uterus of the ewe after exogenous progesterone and oestradiol. Journal of Endocrinology 61, Abstract XXXV.

Schams, D., Barth, D. \& Karg, H. (1980) LH, FSH and progesterone concentrations in peripheral plasma of the female roe deer (Capreolus capreolus) during the rutting season. Journal of Reproduction and Fertility 60, 109-114.

Sempéré, A. (1977) Plasma progesterone levels in the roe deer. Journal of Reproduction and Fertility 50, 365-366.

Sempéré, A.J. \& Lacroix, A. (1982) Temporal and seasonal relationships between $\mathrm{LH}$, testosterone and antlers in fawn and adult male roe deer (Capreolus capreolus): a longitudinal study from birth to four years of age. Acta Endocrinologica 99, 295-301.

Sempéré, A.J., Renaud, G. \& Bariteau, F. (1989) Embryonic development measured by ultrasonography and plasma progesterone concentrations in roe deer (Capreolus capreolus). Animal Reproduction Science 20, 155-164.

Spicer, L.J., Ireland, J.J. \& Roche, J.F. (1981) Changes in serum LH, progesterone, and specific binding of ${ }^{125} \mathrm{I}-\mathrm{hCG}$ to luteal cells during regression and development of bovine corpora lutea. Biology of Reproduction 25, 832-841.

Stieve, H. (1950) Anatomische-biologische Untersuchungen ueber die Fortpflangungstätigkeit des europäischen Rehes. Zeitschrift für mikroskopischeanatomische Forschung 55, 427-530.

Suttie, J.M., Fennessy, P.F., Corson, I.D., Laas, F.J., Elgar, H.J. \& Lapwood, K.R. (1989) LH and testosterone responses to $\mathrm{GnRH}$ in red deer (Cervus elaphus) stags kept in a manipulated photoperiod. Journal of Reproduction and Fertility 85, 213-219.

Van Mourik, S. \& Stelmalsiak, T. (1985) Seasonal variation in plasma prolactin concentration in adult male rusa deer (Cervus rusa timorensis). Comparative Biochemistry and Physiology 82A, 323-328.

Wandeler, A.I. ( 1974) Die Fortpflangzungsleistung des Rehs (Capreolus capreolus) im Berner Mittelland. Naturhistorisches Museum der Stadt Bern Jahrbuch 5 , 245-301.

Received 21 November 1991 